Int. J. Electrochem. Sci., 14 (2019) $9436-9448$

International Journal of

ELECTROCHEMICAL

SCIENCE

WWW.electrochemsci.org

\title{
The Synthesis of Bridging Carbon Particles with Carbon Nanotubes from Areca catechu Husk Waste as Supercapacitor Electrodes
}

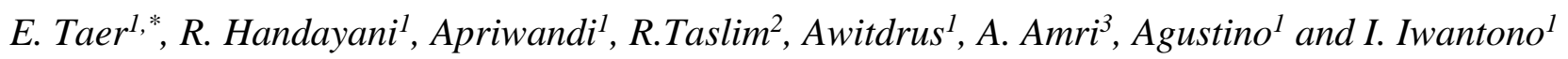 \\ ${ }^{1}$ Department of Physics, University of Riau, 28293 Simpang Baru, Riau, Indonesia \\ ${ }^{2}$ Departement of Industrial Engineering, State Islamic University of Sultan Syarif Kasim, 28293 \\ Simpang Baru, Riau, Indonesia \\ ${ }^{3}$ Department of Chemical Engineering, University of Riau, 28293 Simpang Baru, Riau, Indonesia \\ *E-mail: erman_taer@yahoo.com
}

doi: $10.20964 / 2019.10 .34$

Received: 4 June 2019 / Accepted: 28 July 2019 / Published: 30 August 2019

This study examines the synthesis of carbon particles with nanotubes as electrodes for supercapacitors. The electrodes were made from areca catechu husk without the addition of adhesive materials. There was a multi-activation process including chemical and physical activation using $\mathrm{KOH}$ activator and $\mathrm{CO}_{2}$. Physical activation time is the main factor for consideration in this discussion. The addition of activation time has an effect on the physical and electrochemical properties of supercapacitor electrodes. Carbon hollow fiber is clearly visible on the surface of the electrode with varying sizes of outer and inner diameters in the nanometer range. The results show there was an incredible performance by ACF-2.5 sample activated for 2.5 hours. ACF-2.5 sample delivered optimum capacitive properties of $165 \mathrm{~F} \mathrm{~g}^{-1}$ with a maximum surface area of $757.449 \mathrm{~m}^{2} \mathrm{~g}^{-1}$. Thermogravimetric analysis and the degree of crystallinity were also carried out to strengthen the electrode analysis of supercapacitors.

Keyword: carbon fiber; areca catechu husk; supercapacitor

\section{FULL TEXT}

(C) 2019 The Authors. Published by ESG (www.electrochemsci.org). This article is an open access article distributed under the terms and conditions of the Creative Commons Attribution license (http://creativecommons.org/licenses/by/4.0/). 